and change in Indian foreign policy. The entire book could have been copy-edited for better linguistic appeal. These limitations apart, the book is useful for students, teachers and practitioners of Indian foreign policy.

\author{
P.S. Jayaramu \\ Professor of Political Science \\ Bangalore University \\ Bangalore
}

\title{
Electoral Politics in South Asia
}

\section{Dushyantha Mendis (ed.), Electoral Process and Governance in South Asia (New Delhi: SAGE, 2008), pp. 479. Price ₹ 695.}

DOI: $10.1177 / 002088171004600407$

South Asia is undergoing democratization in varied forms. Apart from the relatively stable democracies of India and Sri Lanka, other South Asian countries too have witnessed revival of democracy. While democratic experiments in Afghanistan, Pakistan and Nepal are facing tough challenges, transition of power in Bhutan, Bangladesh and Maldives is relatively more stable. Electoral processes in all these countries have, however, been encountering certain maladies.

The book is based on papers originally presented at an international conference on electoral process and governance in South Asia organized by the International Centre for Ethnic Studies, Kandy, Sri Lanka, in 2002. The countries dealt with in this volume are India, Pakistan, Nepal, Bangladesh and Sri Lanka. Its main objective is to understand the electoral processes as they operate in these countries and to discuss the reasons for systemic flaws and the success or failure of electoral reforms.

The book is divided into four parts: Part I contains an elaborate introductory chapter by the editor examining the process of democratic transition in South Asia. Part II presents an overview of electoral processes and governance in five selected countries. Part III focuses on the statutory framework and institutional arrangements in these countries. Part IV contains a discussion of group discrimination in elections in these countries.

Though the book was published in 2008, chapters covered the developments until 2005. Also, some of the chapters suffer from bias. For instance, the editor portrays the Indian national struggle (p. 19) as a movement led by India's industrial capitalist class to serve their interest. In reality, the landlords and capitalist class earlier supported the British imperialists. It was only when they too were subjected to open humiliation along with the general masses that they joined the movement. It is also erroneous to say (p. 20) that nothing was done for the peasantry after independence. In fact, soon after independence, the Zamindari system was

International Studies, 46, 4 (2009): 47I-480 
abolished in most Indian states and numerous land reform measures were undertaken to uplift the poor. The result, however, may not have been as radical as expected.

Similarly, the editor rightly discusses the problem of psychological security confronting the South Asian countries, emerging from real or perceived threat to identities of various ethnic groups. But it is difficult to share his view that Nepal is an exceptional case (p. 41). The controversy generated by Nepal's first Vice President, Parmanand Jha, hailing from Nepal's minority community in the Terai region, who took the oath of office in Hindi, shows that Nepal is not free from the challenges to psychological security. The Maoists were able to spread their influence in Nepal not only because of poverty and lack of good governance during the multi-party democracy in Nepal since the 1990s, but also because of insecurity of the country's ethnic minorities.

Taking a cue from Robert A. Dahl's emphasis on requisite consciences, norms and habits for success of democracy, the editor rightly underlines the significance of the long process of indoctrination and habituation for ensuring psychological security. It is in this context that one may find fault with Amit Prakash's otherwise excellent and balanced discussion regarding group discrimination and elections in India. While he rightly discusses how a formal legal structure as well as informal dynamics of Indian politics have empowered the weaker sections of society and minimized the scope of group discrimination, he ignores the contribution of India's political culture in this regard. One may, for instance, feel unhappy with aberrations in Indian secularism, but it can hardly be denied that there is a larger acceptance of secular forces. Even a right-wing political party like the Bharatiya Janata Party (BJP) has proclaimed itself as a 'real secular party committed to providing justice to all and discrimination with none' and dubbed other political formations as 'pseudo secular'. When the BJP's most moderate face, Prime Minister Atal Bihari Vajpayee, failed to contain communal riots in Gujarat, the electorate dumped his party in the 2004 Lok Sabha elections. This perhaps made the 'iron man' of the BJP try to change his image from a Hindu nationalist leader to a moderate leader by praising the founding father of Pakistan, Mohammed Ali Jinnah.

As against Amit Prakash's chapter that ignores the subtle influence of political culture in the working of Indian democracy and secularism, Rasul Baksh Rais clearly acknowledges how informal social structures, values and culture have sustained discriminatory legal regimes in Pakistan (p. 432). He argues for establishing sustained democracy in Pakistan to strengthen popular participation without discrimination. Regarding how to respond to the Pakistan military's role in keeping Pakistan non-democratic, Zulfikar Khalid Maluka emphasizes 'the unswerving resolve of the people to stand against the military dictator's will' (p. 258).

The contributors to this volume suggest several specific measures for strengthening democracy in South Asia. However, as the editor points out, none of these measures attack the sources of the problems associated with electoral processes in South Asia. Excessive politicization is seen in all of them. The editor recommends not only liberalization of economy, but also liberalization of the polity in these 
countries to reduce people's dependence on government largesse and thereby increase the space available for greater activity and assertiveness on the part of civil society organizations. But then, why will political leaders allow liberalization of politics and reduce their capacity for doling out favours? A major strength of the book is that it contains valuable information and analysis about electoral processes and governance in the countries studied.

Nalinikant Jha

Professor, Centre for South Asian Studies

Pondicherry (Central) University

Puducherry

\section{Liberalizing Trade in Services}

\section{Saman Kelegama (ed.), Trade in Services in South Asia: Opportunities and Risks of Liberalization (New Delhi: SAGE, 2009) pp. xiv+306. Price ₹ 750 .}

DOI: $10.1177 / 002088171004600408$

The book is a collection of essays on trade in the services sector in South Asia. It provides a set of policies and strategies for various stake-holders to strike at opportunities. Chapter 1 observes that a significant barrier to growth of trade in services is the lack of free flow of information. The services sector relies on intensive information-driven process. Developing countries' inability to provide a sophisticated aggregate information data has made them lose potential gains. Also, systematic efforts need to be made by the South Asian countries to promote trade in the services sector. Since most of them are strong in this sector, establishing a South Asian Free Trade Area (SAFTA) is a viable way to expand its scope.

Chapter 2 notes that there are large areas of similarities and complementarities among the member-states of the South Asian Association for Regional Cooperation (SAARC) in relation to trade in services which can be mutually exploited to enhance their growth. However, the region by and large is a sensitive one and in order to make a decisive beginning in any cluster of services, a strong political will and proper institutional and regulatory mechanisms are needed. Trade and investment being complementary, it would be an appropriate initiative to include investment and services as key areas of regional co-operation.

The services sector in Pakistan is growing, but that country is yet to create mechanisms to support prioritized sectors. Sri Lanka has huge opportunities to promote trade in services, but to convert them into real gains the country has to undertake domestic reforms, especially concerning non-tariff barriers. In Bangladesh, there is a significant scope to promote its model since skilled and English-speaking professionals can deliver services at cheaper prices to the world 